PNL-SA--20399

DE92 012354

\title{
REDUCING GREENHOUSE GAS EMISSIONS IN CZECHOSLOVAKIA
}

M. Kostalova

J. Suk

S. Kolar

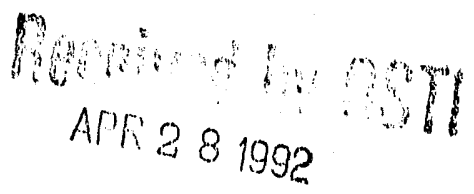

December 1991

Work supported by

the U.S. Environmental Protection Agency

under a Related Services Agreement with

the U.S. Department of Energy

under Contract DE-AC06-76RLO 1830

Pacific Northwest Laboratory

Richland, Washington 99352

DISCLAIMER

This report was prepared as an account of work sponsored by an agency of the United States Government. Neither the United States Government nor any agency thereof, nor any of their employees, makes any warranty, express or implied, or assumes any legal liability or responsibility for the accuracy, completeness, or usefulness of any information, apparatus, product, or process disclosed, or represents that its use would not infringe privately owned rights. Reference herein to any specific commercial product, process, or service by trade name, trademark, manufacturer, or otherwise does not necessarily constitute or imply its endorsement, recom. mendation, or favoring by the United States Goverument or any agency thereof. The views and opinions of authors expressed herein do not necessarily state or reflect those of the United States Government or any agency thereof. 
Marie Kostalova, Jiri Suk, and Stanislav Kolar present important findings in this paper on the potential for energy conservation and carbon emissions reduction over the coming decades in Czechoslovakia. The authors describe the state of energy use in Czechoslovakia loday and the measures required to transform its energy system to a marketbased economy oriented towards the environmental goal of decreased energy intensity. This work furthers our understanding of the need for energy efficiency in the new/y forming market economies of East and Central Europe.

This paper is part of a series of country studies sponsored by the Global Climate Division of the Office of Policy, Planning, and Evaluation, United States Environmental Protection Agency (EPA). We have completed similar studies in Canada, the for- mer Soviet Union. France, Hungary, Ltaly, Japan, Poland, the United Kingdom, and the United States. Research is currently underway or planned in Bulgaria, Romania. and Ukraine.

Our approach to each country study has been to find the best indigenous analysts to perform the work. This method enables us to benefit from the experience and knowledge of regional experts. Marie Kostalova played an integral role in developing new energy policy after the Czechoslovak revolution of 1989 and has continued to provide vital new leadership in Czechoslovakia. Jiri Suk and Stanislav Kolar (now a U.S. citizen) have served as influential analysts of Central European energy problems, and contributed originality and resourcefulness to this research. We are grateful to them for their cooperation, dedication, and quality work.

William U. Chandler

Director, Advanced International Studies 


\section{CONTENTS}

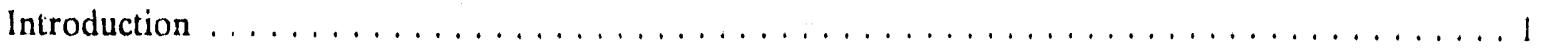

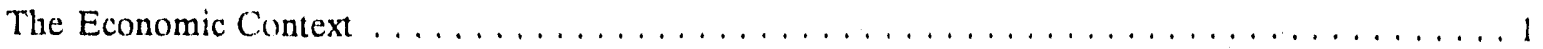

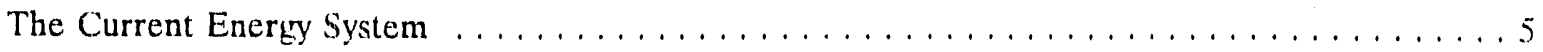

Carbon Dioxide Emissions Reduction Potential $\ldots \ldots \ldots \ldots \ldots \ldots \ldots$

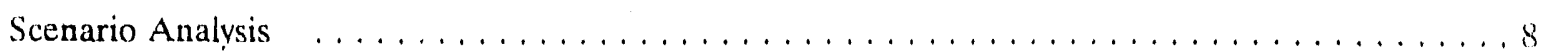

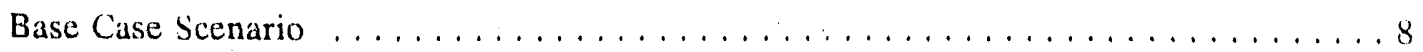

Structural Change Scenario $\ldots \ldots \ldots \ldots \ldots \ldots \ldots \ldots \ldots \ldots \ldots \ldots \ldots \ldots$

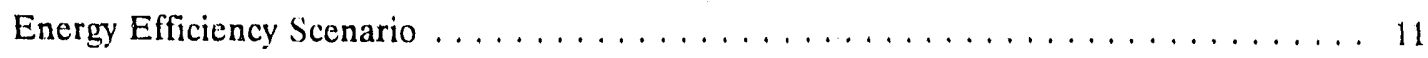

Interfuel Substitution Scenario $\ldots \ldots \ldots \ldots \ldots \ldots \ldots \ldots \ldots \ldots$

Policies for Carbon Dioxide Emissions Reduction and International

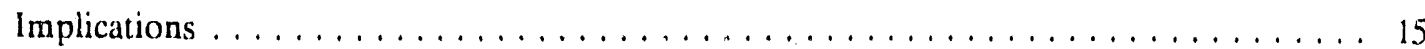

Economic Incentives and Disincentives $\ldots \ldots \ldots \ldots \ldots \ldots \ldots \ldots \ldots$

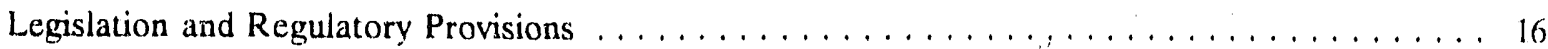

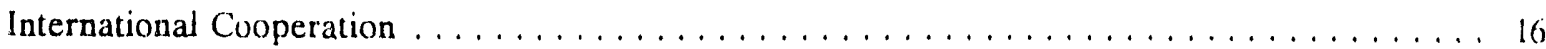

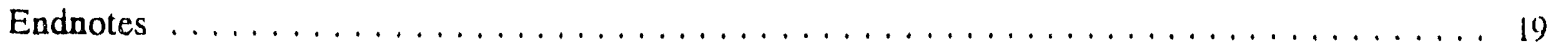




\title{
REDUCING GREENHOUSE GAS EMISSIONS IN CZECHOSLOVAKIA
}

\author{
Marie Kostalova(a) \\ Jiri Suk ${ }^{(b)}$ \\ Stanislav Kolar ${ }^{(\mathfrak{c})}$
}

\section{INTRODUCTION}

Czechoslovakia is a central European country of 1.5.6 million people with industrial, entrepreneurial, and cultural traditions dating back mure than one thousand years. The country is an important case study in whether the transition from a planned cconomy to a market system can be successful. Occupying the very center of Europe, it is becoming an important link between the industrialized West and the struggling East. The country is in a state of relative poverty trom decades of forced economic integration into the Soviet regime, facing a devastated economy and a broken work morale. The fate of Czechoslovakia's current economic transformation will stand as either an example of success or failure in economic management.

It is important to determine whether environmental protection and global concerns can receive sufficient attention in Czechoslovakia and in other nations which are groping to shed the legacy of a totalitarian past. During the next twenty years or so, these countries will experience a period of catching up with the material well-being of western industrialized countries. Thus it will become increasingly important for them to combine economic development with environmental protection.

Czechoslovakia's economy virtually stagnated during the 1980s when real gross domestic product (GDP) growth rate averaged only 1.1 percent per year. One should therefore appreciate that the people would like to achieve greater economic benefits in the coming decades (Table 1). Energy efficiency could help Czechoslovakia's economic development, while simultaneously improving the environmental situation by reducing carbon, sulfur, and particulate emissions.

Table 1. Population and Economic Variables for Czechoslovakia, 1980 to 2030

\begin{tabular}{lllll}
\hline & 1980 & 1990 & $2005^{\circ}$ & $2030^{\circ}$ \\
\hline $\begin{array}{l}\text { Population } \\
\text { (Millions) }\end{array}$ & 15.3 & 15.7 & 16.3 & 16.7 \\
$\begin{array}{l}\text { GDP/Capita } \\
(1985 \text { USD) }\end{array}$ & 6136 & 6843 & 9303 & 21.457 \\
\hline
\end{tabular}

- Estimates

Source: Marer, 1985; CLA, 1989.'

\section{THE ECONOMIC CONTEXT}

In 1948, the last of the "people's democracies" in Europe was established in Czechoslovakia by way of a communist putsch. The events in 1948 interrupted an era of harmonious free market development, which had lasted from 1918 to 1939 and continued from 1945 to 1948. Prior to World War II, Czechoslovakia was among the ten most developed nations in the world, as measured by per capita income. The country was home to some of the finest automobile, motorcycle, machine tool, engineering, and footwear companies in the world. Its surplus wealth was exported to western Europe, creating an important link in East-West trade.

(a) Director, Office of International Economic Cooperation, Ministry of Foreign Alfairs, Prague.

(b) Institute for Forecasting, Czechoslovak Academy of Sciences, Prague.

(c) Pacific Northwest Laboratory, Washington Operations, Washington, D.C., operated by Battelle Memorial Institute for the U.S. Department of Energy. 
Czechoslovakia has been an indispensable part of communist economic development since 1948 , serving as a depository of obsolete technology and outmoded products, and as a supplier of heavy engineering products, crude steel, and armaments to the entire Socialist world. Czechoslovakia helped preserve the Soviet system of economic inefficiencies, bringing about the country's own ills.

Czechoslovakia underwent extraordinary forced industrial expansion during the 1950s. Stcel, cement, and chemicals production were given priority over consumer goods. As a result, the country now has one of the largest industrial capacities in the world, as measured by the production of key industrial products per capita. In a representative sample of 11 key industrial commodities produced per capita, Czechoslovakia tops the list in seven items, and is among the top three countries in the remaining four conmodities. A great part of these industrial capacities is underutilized, however, due to low economic effectiveness and high material, capital, and labor intensities, and particularly, the lack of comprative advantage in production.

This extraordinary industrial overdevelopment has created economic difficulties in Czechoslovakia. The industrial sector claims a lion's share in employment, investments, and imports, and is largely responsible for the country's high energy consumption (Tables 2 and 3 ).

Taisle 2. Share of Industry in Economic Indicators, 1980s

Czechoslovakia OECD Average

\begin{tabular}{lll} 
& \multicolumn{2}{c}{ (Percent) } \\
Employment & 38 & 25 \\
Energy Consumption & 59 & 37 \\
Investments & 35 & 24 \\
Imports & 87 & 40 \\
GDP & 37 & 28
\end{tabular}

Source: Institute for Forecasting. ${ }^{2}$

Primary energy consumption in Czechoslovakia amounts to 190) gigajoules (GJ) per capita, compared to $96 \mathrm{GJ}$ in Italy, $109 \mathrm{GJ}$ in Japan, 112 ( $3 J$ in Switzerland, 116 GJ in Austria, and 118 GJ in France (Figure 1). Energy demand per dollar o: gross domestic product (GDP) is approximately 2.5 times higher in Czechoslovakia than in most of western Europe (Figure 2).

Table 3. Share of Heavy Industry in Economic Indices. 1985

Caechoslovakia OECD Average

\begin{tabular}{lll} 
& \multicolumn{3}{c}{ (Percent) } \\
Total GDP & 20 & 12 \\
Gross Investments & 24 & 10 \\
Total Employment & 18 & 9
\end{tabular}

Source: Institute for Forecasting.

The country's factories turn out immense quantities of energy-intensive products. Steel consumption amounts to $717 \mathrm{~kg}$ per capita, compared to an average of 250 to $500 \mathrm{~kg}$ in western Europe. Steel consumption per dollar of GDP is 3 to 4 times higher in Czechoslovakia than in western Europe. A similar pattern can be observed for cement. plastics, artificial fibers, and artificial fertilizers. In the West, material processing industries contribute about 25 percent of total industrial output, but in Czechoslovakia these industries account for 35 percent of industrial GDP. As a result, more than half of the country's energy is consumed in the industrial sector, compared with an average of 35 percent for the Organization for Economic Cooperation and Development (OECD) countries (Table 4).

Table 4. Final Energy Consumption in Czechoslovakia by Sector. 1088

\begin{tabular}{lcc}
\hline & Petajouler (VJ) & Percent of Total \\
\hline industry & 1126 & 54 \\
Transport & 86 & 4 \\
Agriculture & 120 & 6 \\
Residential & 449 & 22 \\
Commerctal & 307 & 15 \\
& & \\
TO'TAL & 2088 & 100
\end{tabular}

Source: Henel and Cabicar, Iyg(t.3 


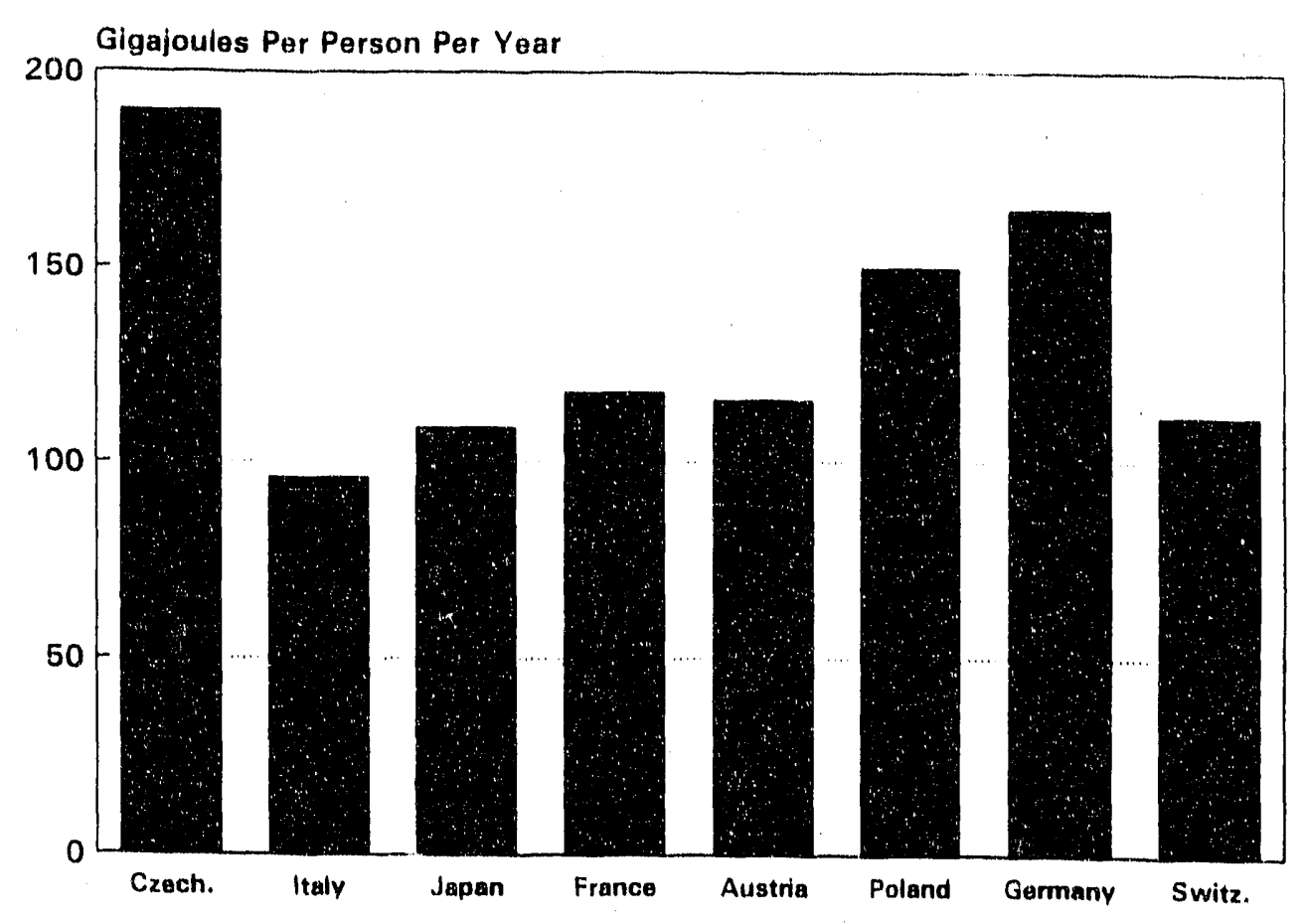

Figure 1. Energy Consumption Per Capita, 1988

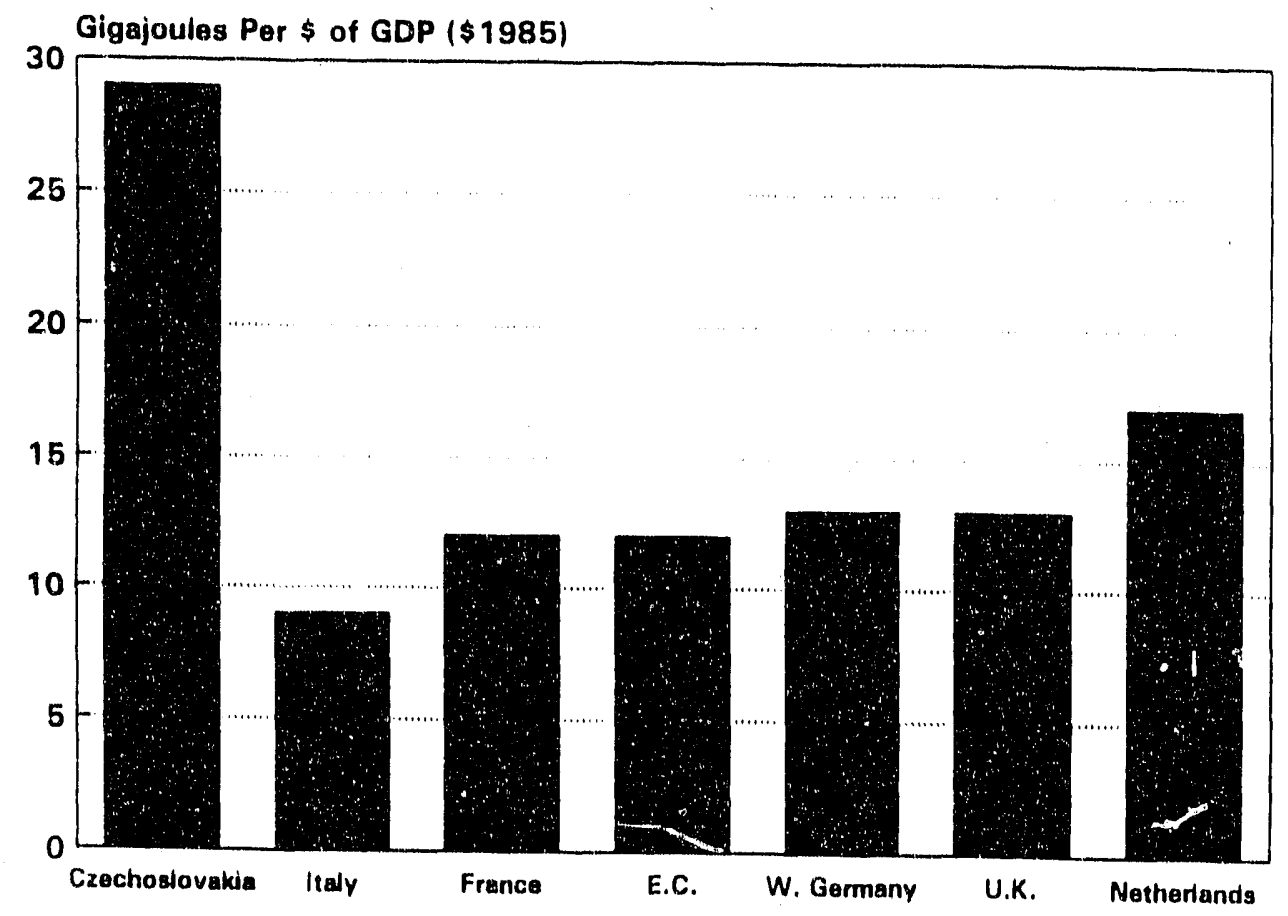

Note: listimates used for Czechoslovakia are 1990 figures: all others are 1988 figures.

Figure 2. Energy Intensity of National Income (Source: CIA, 1989) 
Table 5. Prices Per Kilogram of Czechoslovak Products Exported to the European Community Compared to World Prices

\section{Prices (\$ per Kg)}

EC to World

CSFR to EC CSFR as \% of EC

Engineering (1985)

7.36

1.80

25

Chemicals (1986)

1.15

0.60

52

Consumer Goods (1986)

$\begin{array}{lccc}\text { Textile Yarn } & 6.35 & 3.49 & 55 \\ \text { Clothing } & 30.74 & 13.87 & 45 \\ \text { Leather, Footwear } & 17.38 & 5.66 & 33 \\ \text { Woodwork } & & & \\ \text { Printing } & 1.9 & 50.39 & 20 \\ \text { Glass, Ceramics, China } & 4.27 & 1.48 & 35 \\ & 1.4 & 30.69 & 48\end{array}$

Source: Institute for Forecasting.

Human and capital resources in Czechoslovakia are extremely underutilized. Labor productivity is approximately 50 to 60 percent that of developed countries, and capital intensity of production is more than twice as high. The underutilization of production inputs is reflected in the low price per kilogram of products exported to the European Community (Table 5). This creates a vicious circle where the country cannot modernize its industrial infrastructure because it does not earn enough hard currency to purchase the latest equipment.

Macroeconomic imbalance has resulted from the distorted economic policies of the former Council for Mutual Economic Assistance (CMEA), in which Czechoslovakia played a major role. Multi-national comparison shows that the heavy engineering sector, especially in areas of mining, metallurgical, chemical equipment, and freight transportation, was particularly overemphasized to satisfy CMEA demand for these products. For example, Czechoslovakia produced 60 percent of the diesel locomotives and 26 percent of the steel in the CMEA countries (excluding the Soviet Union), while representing only 14 percent of the population. Consequently, many areas of economic development have been underemphasized, such as consumer products, passenger automobiles, electronics, furniture, and pulp and paper (Table 6).

Table 6. Czechoslovakia's Share in Producing Selected Commodities within Six CMEA Countries'

\begin{tabular}{lc}
\hline & (Percent) \\
Population & 13 \\
Diesel Locomotives & 60 \\
Electric Locomotives & 33 \\
Crude Steel & 27 \\
Tractors & 25 \\
Cement & 18 \\
& \\
Refrigerators & 14 \\
TV Sets & 14 \\
Radios & 5 \\
Cameras & 3
\end{tabular}

- CMLA Six are: Bulgaria, Czechoslovakia, Last Germany (before reunification in 1990), Hungary, Poland, and Romania. Data are from early 1980s or from 1988.

Source: Nove, $1982 .^{4}$ 


\section{THE CURRENT ENERGY SYSTEM}

A significant share of total energy demand is $\mathrm{ex}$ pended in the industrial sector, representing a large share of coal in the primary energy balance. The unergy intensity of the country's economy is 2.5 limes as great as that of the Federal Republic of Germany before reunification in October 1990. Thus, Czechoslovakia needs almost 2.5 times as much energy as Germany to produce one dollar of its GDP (Figure 2).

The development of the energy supply system in Czechoslovakia over the last forty years can be divided into two stages. The first stage was characterized by extensive growth in the production of domestic energy resources. mainly coal, to satisfy the needs of growing heavy industry. The second was a period of increased energy imports from the Soviet Union. Between 1950 and 1960, primary energy consumption in Czechoslovakia grew 70 percent. Hard and brown coal consumption rose by 48 percent and 97 percent, respectively. Energy imports uncreased by about half, while exports rose by three-fourths.

The share of coal in Czechoslovakia's primary energy balance over the years has been high compared to international standards. In 1960, coal supplied 90 percent of the country's energy, while it only provided three-quarters and one-half of energy in West Germany and Austria, respectively. Due to Czechosiovakia's proximity to the Soviet Union and to Soviet policies, the option of importing energy resources from other countries was never considered, and at the time, the Soviet Union did not produce enough oil or natural gas to guarantee supplies of these fueis to Central Europe.

Significant changes took place in Czechoslovakia's energy policy after 1960. Growth in domestic production of energy slowed, while crude oil and natural gas imports from the Soviet Union grew to satisfy new demand. In addition, an ambitious nuclear program was launched using Soviet technology. The country's domestic energy production increased only 40 percent between 1960 and 1988, while energy imports grew by nearly six times. Domestic coal production increased again, however, after 1980 (Table 7). Coal currently meets 61 percent of Czechoslovakia's energy needs, oil 22 percent, and natural gas only 11 percent. The remainder, about 6 percent, is supplied by nuclear and hydro power (Figure 3).

Table 7. Primary Energy Consumption in Czechosloyakia by Fuel, 1985

\begin{tabular}{lcc}
\hline & Petajoules (PJ) & Percent of Total \\
\hline Coal & 1912 & 61 \\
Oil & 673 & 22 \\
Natural Gas & 343 & 11 \\
Primary Electricity & & \\
and Heat & 195 & 6 \\
TOTAL & 3123 & 100 \\
\end{tabular}

Source: Henel and Cabicar, 1990.

This period also saw an expansion of the country's electricity supply. Electricity's share in final energy demand grew from 16.4 percent in 1955 to 25 percent today. Expansion of electricity consumption was made possible by the Soviet Union's ambitious nuclear program. The first nuclear reactor was commissioned in the early 1970 s; to date, 8 reactors are in operation, and 6 or 8 more arc planned for the next 10 to 15 years. Nuclear power currently supplies the country with 26 percent of its electricity needs (Table 8). Czechoslovakia's per capita consumption of electric power is about the same as the European average (Figure 4). However, sectoral use of electricity is markedly different. Households consume only about 14 percent of all electricity, while the industrial sector consumes almost two-thirds. Western Europeans consume more than 20 percent of their electricity in households.

The Czechoslovak authorities have tried in the past to reduce the country's high energy intensity by introducing energy-efficiency measures as part of socalled "rationalization programs." These programs proved somewhat successful in reducing growth of energy consumption in the early 1980s, but failed to reduce the economy's high energy intensity. This was primarily because they rendered administrative directives rather than economic incentives (Figure 5). Where these programs did succeed, they relied on administrative solutions to high energy intensity. At best, they achieved a rate of energy intensity reduction similar to that of the West in the 1980s. 


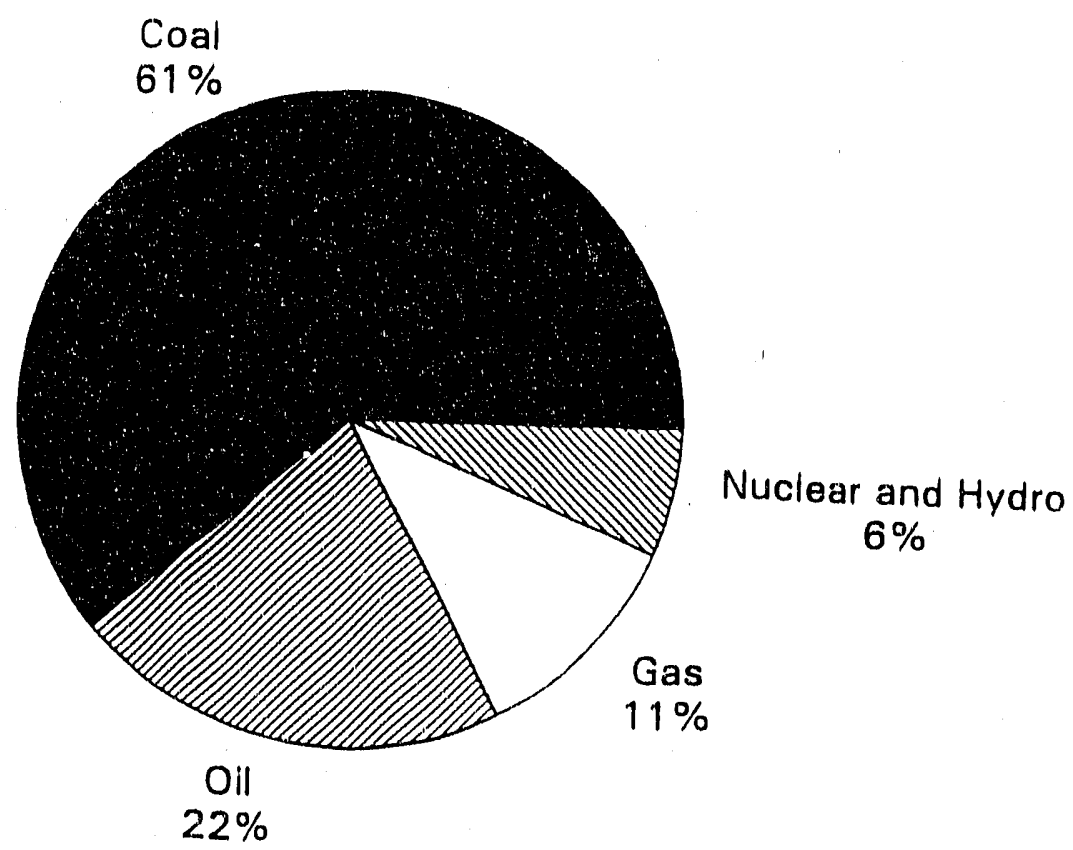

Figure 3. Energy Supply in Czechoslovakia, 1988

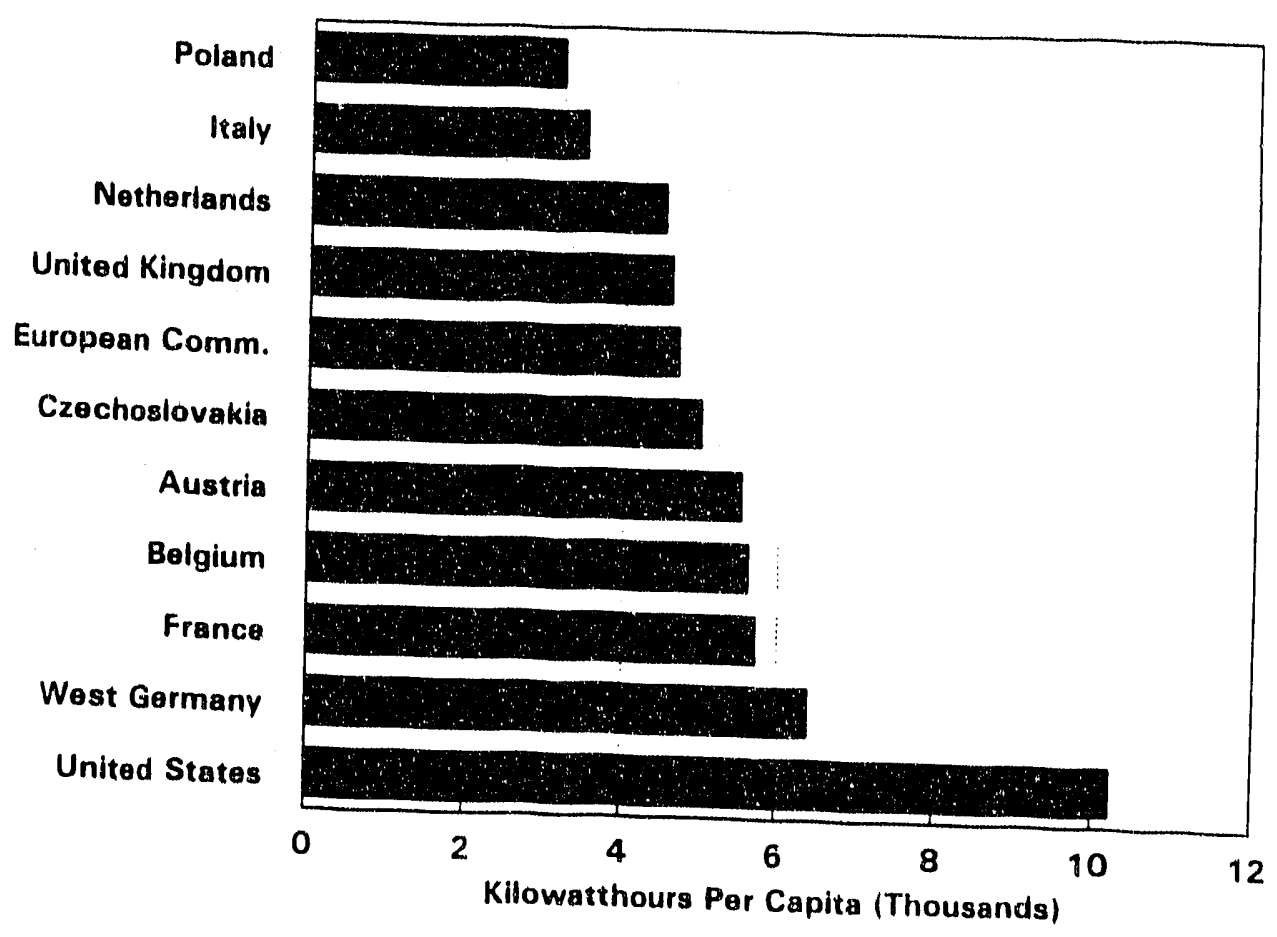

Figure 4. Electricity Consumption, 1988 (Source: CLA, 1989) 
However, because energy intensity was initially much higher in Czechoslovakia, rates were lower than might have been expected.

'Table 8. Production of Electric Energy in Czechoslovakia, 1988

TWh

Percent

Power Plants:

\begin{tabular}{lcc} 
Thermal & 610.6 & 104 \\
Hydro-Electric & 4.1 & 4 \\
Nuclear & 24.6 & 20 \\
Imports & 6.7 & 7 \\
Gross Consumption & 95.4 & 100 \\
\hline
\end{tabular}

Source: Henel and Cabicar, 1990.
Table 9. Carbon Dioxide Emissions trom Fossil Fuels, 1985

By fuel: Million tons of Carbon

Percent of Total

$\begin{array}{lcc}\text { Coal } & 47 & 73 \\ \text { Oil } & 13 & 20 \\ \text { Vatural cias } & 5 & 7\end{array}$

TOTAL $\quad 0.5^{\circ} \quad 100$

By Sector:

$\begin{array}{lcc}\text { Industry } & 45 & 68 \\ \text { Bulldings } & 15 & 24 \\ \text { Transport } & 5 & 8 \\ \text { TOTAL } & 65 & 100\end{array}$

Source: Authors

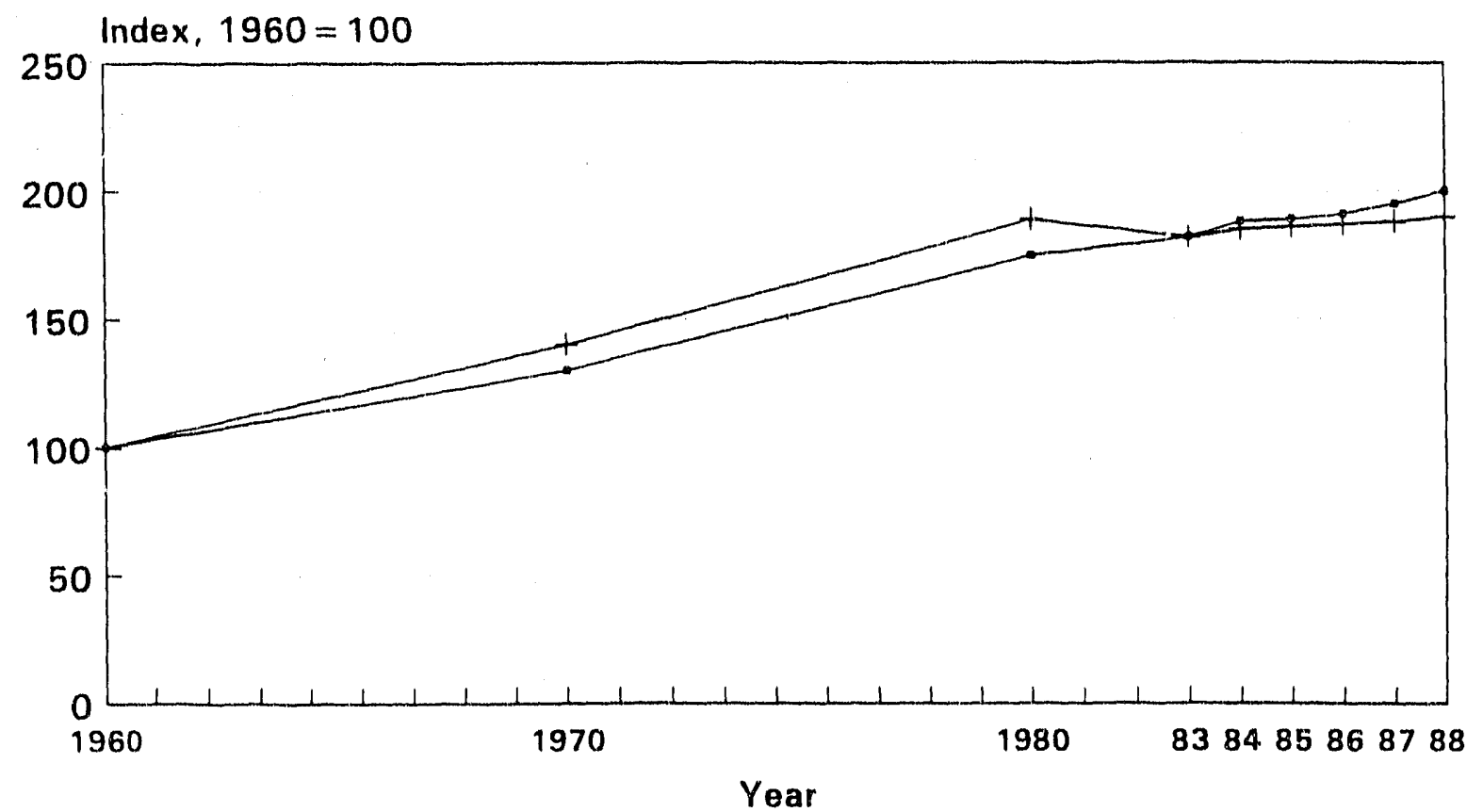

GDP - Energy Consumption

Figure 5. Energy Intensity in Czechosiovakia, Energy/GDP Ratio (Source: CIA, 1989) 


\section{CARBON DIOXIDE EMISSIONS REDUCTION POTENTIAL}

Annual carbon dioxide emissions in Czechoslovakia amounted to 6.5 million tons of carbon in 1985. The industrial sector contributed 68 percent of this total. while buildings and transport accounted for 24 and 8 percent, respectively. In contrast, in the United States, each of the three sectors contributed approximately one-third of total carbon emissions. Coal was by far the largest source of carbon emissions in Czechoslovakia with 73 pereent of the share, lollowed by oil and natural gas with 20 and 7 percent, respectively (Table 9).

The future energy system in Czechoslovakia could play a key role in reducing carbon emissions. Carbon dioxide emissions reduction, however, is not a high priority in Czechoslovakia's current environmental policy. The reduction potential depends instead on economic and energy development policies, and whether carbon emissions reduction can be tied to other environmental threats in the country such as acid rain, smog, and urban ozone pollution. Carbon emissions reduction thus depends on how quickly economic activity can be reduced in the most energy-intensive industries, and how well energy efficiency measures are adopted. Industrial restructuring, for example, means producing less steel and aluminum, but more plastics and VCRs. Energy efficiency means decreasing energy use to achieve the immediate environmental goals of reducing local pollutants.

Economic restructuring will most likely happen without any major interventions by the government. The current policy of gradually removing industrial subsidies is expected to force many inefficient producers out of business. The question is to what extent this will occur and how quickly. The most important tools the government has in regulating what is produced are price controls and subsidies. By eliminating both of these, the economy can fully adapt to market conditions over several years. Czechosiovakia has an export-oriented economy and thus cannot remain immune to international economic developments. With Soviet influence largely ended, Czechoslovakia is bound to be affected by economic and political developments in the West.

The government's role would have to be more pronounced in order to reduce specific energy intensity, decreasing the amount of energy it takes to produce one unit of national income. A comparison of the energy intensity of Czechoslovakia and western European nations vields a revealing statistic: Czechoslovakia uses more than twice as much energy to produce one unit of (3DP (Figure 2). Czechnslovakia cannot both increase its living standards and maintain such high levels of energy consumption. If it did, conergy supply would consume an ever-increasing share of capital, leaving little to invest in other sectors.

The essential leature of Czechoslovakia's energy policy must be a reduction of energy end-use intensity. The nation must also reduce its reliance on low quality fossil fuels.

\section{SCENARIO ANALYSIS}

We have used the U.S. Environmental Protection Agency's (EPA) energy end-use model ${ }^{5}$ to generate our estimates of the cost-effective technical potential for reducing carbon dioxide emissions in Czechoslovakia through the year 2030. Four scenarios have been developed: the Base Case Scenario, the Structural Change Scenario, the Energy Efficiency Scenario, and the Interfucl Substitution Scenario.

\section{Base Case Scenario}

The Base Case Scenario assumes that current economic trends will change to reflect the present government's commitment to restructuring the economy. The impact of economic reforms would have to be accompanied by industrial, agricultura!, and energy policies, much like government regulation in market economies. In other words, the role of the government would not be eliminated, but limited to liscal and monetary policies, in addition to outlining broad national priorities. At the same time, the government would have to introduce foreign trade policies designed to open Czechoslovakia's economy to the world.

The Base Case Scenario assumes that growth in the production of ferrous metallurgy, non-ferrous netallurgy, chemicals, and cement will either slow down or reverse. This scenario, however, does not assume that there will be additional changes in carrent economic trends; for example, in investment 
allocation, patterns of energy end-use demand, and technical energy efficiency. The Base Case Scenario thus captures only the most significant and most likely changes proposed by the present leadership.

The Base Case, despite the lack of energy-elficiency policy, results in only a 24 pereent increase in

'Table 10. Energy Demand in Czechostovakia, 198.5 to 2030

\begin{tabular}{llll}
\hline Scenario: & 1985 & 2005 & 2030 \\
\hline Base Case & 3123 & $(\mathrm{PJ})$ & \\
Structural Change & 3123 & 3300 & 3870 \\
Energy Efficiency & 3123 & 2840 & 3250 \\
Interfuel Sub- & 3123 & 2290 & 2430 \\
Stitution & & 2290 & 2430 \\
\hline
\end{tabular}

Source: Authors. primary energy consumption by the year 2030 (Table 10). This is largely due to the dramatic drop in primary materials production in Czechoslovakia. Carbon dioxide emissions in this scenario will grow by 15 pereent between 1985 and 2030 (Table 11 and Figure 6). The carbon-to-energy ratio would decline over this period on the assumption that the role of nuclear power in electricity generation will increase.

Table 11. $\mathrm{CO}_{2}$ Emissions in Czechoslovakia, 1985 to $2(1) 30$

\begin{tabular}{|c|c|c|c|}
\hline Socnario: & 1085 & 2001.5 & 20130 \\
\hline & \multicolumn{3}{|c|}{ (Million Tons of Carbon) } \\
\hline Base Case & 64.7 & 66,5 & 74.3 \\
\hline Structural Change & 64.7 & 57.7 & $6,6.1$ \\
\hline Energy Efficiency & 64.7 & 46.2 & 17.1 \\
\hline $\begin{array}{l}\text { Interfuel Sub- } \\
\text { stitution }\end{array}$ & 64.7 & 40.4 & $\$ 1.1$ \\
\hline
\end{tabular}

Source: Authors.

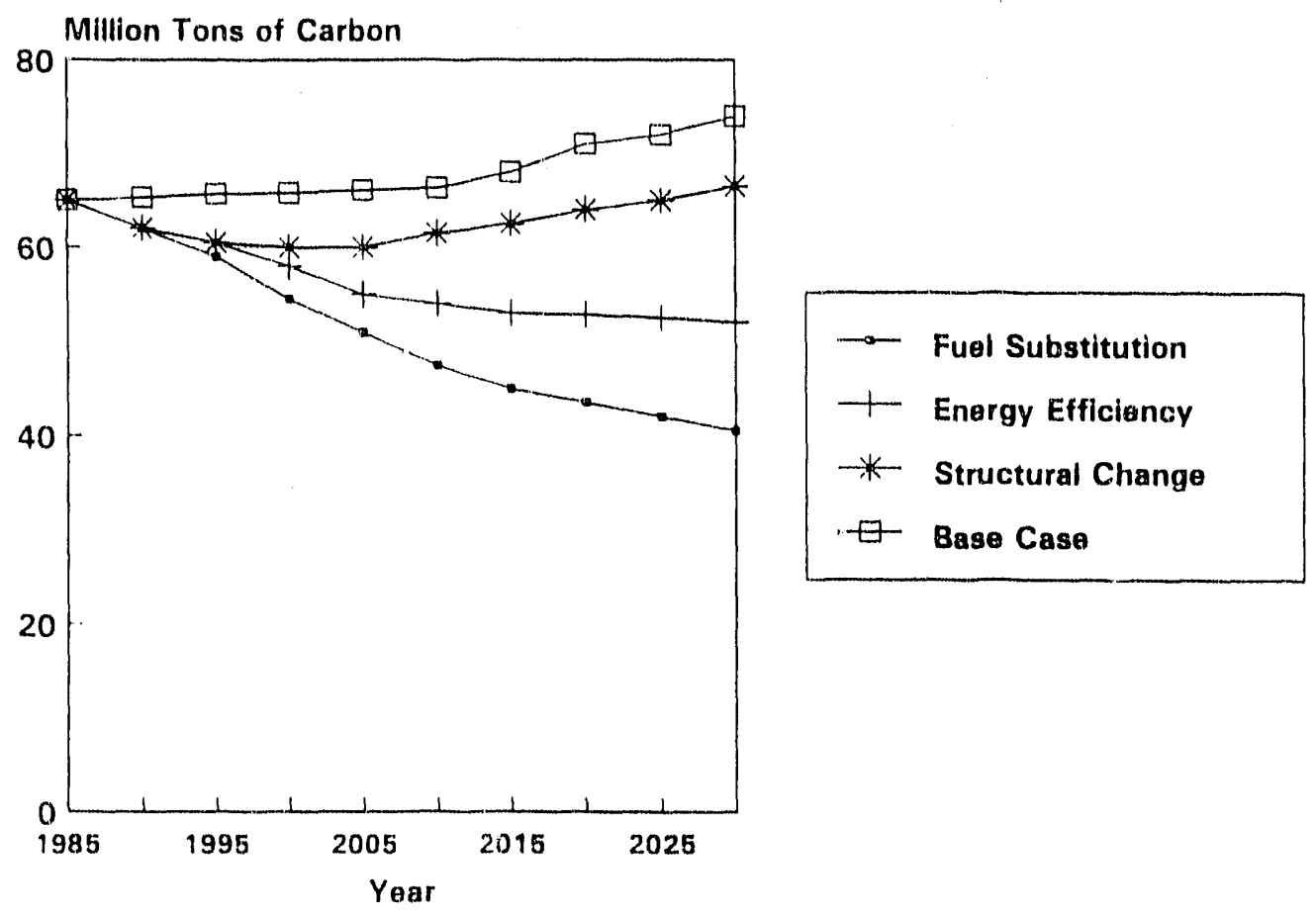

Figure 6. Carbon Emissions Scenarios for Czechoslovakia (Source: Authors) 


\section{Structural Change Scenario}

Structural change in our model is characterized as the ratio of growth of each of five industrial (twodigit stanaard industrial classification (SIC) | sectors to the overall growth in GDP. plus an additional sector for general manufacturing. ${ }^{\circ}$ Structural change affects the energy intensity of the economy because shifting levels of energy-intensive activities changes the overall energy use pattern. There are wide variations in energy intensities of different economic sectors and subsectors. and changing the relative shares of these sectors in economic activity will have a profound effect on overall caergy use per unit of GDP.

One area in which Czechoslovakia's economy differs from those of most developed industrial nations is the excessive share of metallurgical and basic materials production in total industrial output. Machinery and equipment for mining, transport. and raw material processing industries account for about 35 percent of the rolled stock consumed in the entire engineering sector, or approximately 2 million tons per year. Economic restructuring would most likely effect a much lower production of these energy-intensive products. Consumption of rolled steel stock, for example, should be reduced in the engineering, construction, and export sectors. Further energy savings can be achieved by a modernization of the metallurgical technology--.continuous casting is one example. These changes in the heavy metallurgy sector would reduce energy consumption by about 125 petajoules (PJ) (Table 12).

Table 12. Industrial Restructuring and the Corresponding Decrease in Energy Demand, 1990 to 20000

Restructuring
Measures in:

Heavy Metallurgy

Chemicals

Other Industres

TOTAL

$488-513$

Source: Authors.

A further reduction of energy consumption would be possible in the chemical sector. Improving plastic production processes and the production of polyethylene, as well as phasing out the production of nitrogen fertilizer and ammonia using obsolete technology could save the chemical sector 38 petajoules of energy consumption.

Additional measures to curb energy consumption include reducing output in other energy-intensive industries, such as cement and ore mining, improving technical innovation in engineering by relving on computer-controlled processing, and liquidating surplus industrial capacitics. These steps can save an additional 325 to 350 petajoules of energy before the end of the century.

The energy savings which would result from these changes relate to structural and sometimes process changes in the industrial sector. They do not capture the potential for technical energy efficiency in industry, or energy saving possibilities in the residential, commercial, and transportation sectors. Therefore, these energy-saving measures incur no net costs, because they would occur even if one did not intend to save energy.

As Czechoslovakia moves away from its traditional role as a CMEA supplier of heavy engineering products, raw steel, and chemicals, investments will be increasingly allocated to light and electronics industries and to the service sector. Furthermore, the country will likely become a fully integrated partner of the European Cornmunity within the next decade. These future developments will transform the nations' economy from its current base of primary materials to a post-industrial western economy.

The EPA energy end-use model can be used to chart these developments in five-year increments. We have assumed that in addition to the decreasing share of primary metals and materials processing industries in the economy, the service and personal consumption ${ }^{7}$ sectors will substantially increase their shares in total economic activity.

The combined effect of industrial restructuring in the heavy metallurgy, chemicals, and basic materials industries, as well as in some other energy-intensive industries. would save approximately 500 petajoules per year. Following the assumption that the nonindustrial sectors will grow. energy consumption in the industrial sector could decrease by 25 percent by 
2030. The countrys total primary energy consumption, however, would increase by 5 percent.

This estimate is based on the expectation that the residential, commercial, and transportation sectors will increase their shares of total economic activity and energy consumption. Just as industry's share would decline to approximately match the level in similar western European countries, we assume that residential space per capita will gradually grow to a level matching the European average of about 35 square meters per capita by 2030. Similarly, the number of cars per person will change from less than 0.2 today to about 0.4 by year 2030 .

Overall, carbon dioxide emissions in the Structural Change Scenario would initially decline by 10 percent below the current level by 2005 , but would return to approximately today's level around 2025 (Figure o).

\section{Energy Efficiency Scenario}

The Energy Efficiency Scenario incorporates technological improvements in end-use energy efficiency in each of the sectors and subsectors identified in the EPA model. According to this scenario, actual energy consumption will decline to less than 80 percent of the current level by the year 2030 . Following discussions with analysts and energy experts in Czechoslovakia, we derived assumptions for this scenario according to our best estimate of what is technically and economically feasible for the country over the next 40 years.

In order to ascertain the level of energy intensity attainable by pursuing a vigorous energy conservation policy, we made conscientious comparisons of current energy intensity in Czechosiovakia and energy intensity in western in dustrialized nations. The reader should note that this scenario goes beyond the changes simulated in the Structural Change Scenario in that the Energy Efficiency case also captures technological energy-efficiency improvements.

Included in our scenario are several site-specific energy-saving options compiled by VUPEK, a government funded energy research institute in Prague. Although these measures capture only a fraction of the total energy-savings potential in
Czechoslovakia. they offer the most reliable cost data available today. We have compared this data with our estimates of energy-savings potential in Czechoslovakia (Table 13).

The average cost of supplying new energy in Czechoslovakia is around 60 koruna per gigajoule (GJ), while the marginal cost is much higher. Thus, energy conservation is much cheaper than supplying new energy.

Electricity savings account for 8 percent of the total energy savings. The average cost of saving this amount of electricity is 166 koruna per MWh (about $\$ 1.75$ per (GJ), while the cost of supplying new electricity with nuclear power is 517 koruna per MWh (about $\$ 5.40$ per $G J) .8$

We have identified a broad range of energy-saving options (Table 14). These options are specific to each industry or sector, rather than to individual sites or plants. They include:

Iron and steel industry: continuous casting; replacement of the open hearth furnace with the basic oxygen furnace; continuous hot rolling and finishing lines; use of convertor gas in the production process; greater use of electric ovens in steel production and improved use of waste gases produced in electric ovens; heating of scrap metal by using convertor gas and waste gases from electric ovens; and modernization and computerization of production processes.

Non-ferrous metallurgy: replacement of HallHeroult aluminum reduction cells with the Alcoa process.

Cement production: conversion from wet to semidry and dry production processes and increased use of fly ash from coal power stations as a cement additive.

Petrochemical industry: replacement of obsolete technology in styrene production; scrapping carbide/ acetylene installations; and greater use of hydrocracking facilities, for a savings of $10 \mathrm{PJ}$ per year.

Residential and commercial sector: improved building insulation, which alone can save $120 \mathrm{PJ}$ per year at a cost of about 11 billion koruna, with a 
Table 13. Selected Site-Specific Energy Savings and Their Costs in Czechoslovakia

\begin{tabular}{|c|c|c|c|c|c|c|}
\hline Measure & $\begin{array}{c}\text { Total } \\
\text { Cost } \\
\text { Billion Koruna) }\end{array}$ & $\begin{array}{c}\text { Energy } \\
\text { Savings } \\
\text { (PJ/Year) }\end{array}$ & $\begin{array}{l}\text { Lifetime } \\
\text { (Years) (N }\end{array}$ & $\begin{array}{l}\text { Levelized } \\
\text { Cost } \\
\text { (illion Koruna) }\end{array}$ & $\begin{array}{c}\text { Cost of } \\
\text { Conserved Energy } \\
\text { (Koruna/Gigajoule) }\end{array}$ & $\begin{array}{l}\text { Pauback } \\
\text { (Years) }\end{array}$ \\
\hline District Heating & 5.38 & 12.75 & 28 & 443.3 & 34.8 & 4.7 \\
\hline Small Hydro Plants & 0.34 & 0.9 & 37 & 25.9 & 28.8 & 4.2 \\
\hline Continuous Casting & 4.9 & 11.74 & 23 & 434.7 & 37.0 & 4.6 \\
\hline Fluorescent Lights & 0.44 & 7.14 & - & +8.3 & 6.8 & 0.7 \\
\hline $\begin{array}{l}\text { New Buildings } \\
\text { Insulation }\end{array}$ & 0.41 & 36.23 & . & 38.7 & 1.1 & 0.1 \\
\hline Other & 2.37 & 17.57 & 21 & 218.7 & 12.4 & 1.5 \\
\hline TOTAL & 13.84 & 80.33 & - & 1209.6 & - & \\
\hline
\end{tabular}

Source: Henel and Cabicar, 1990.

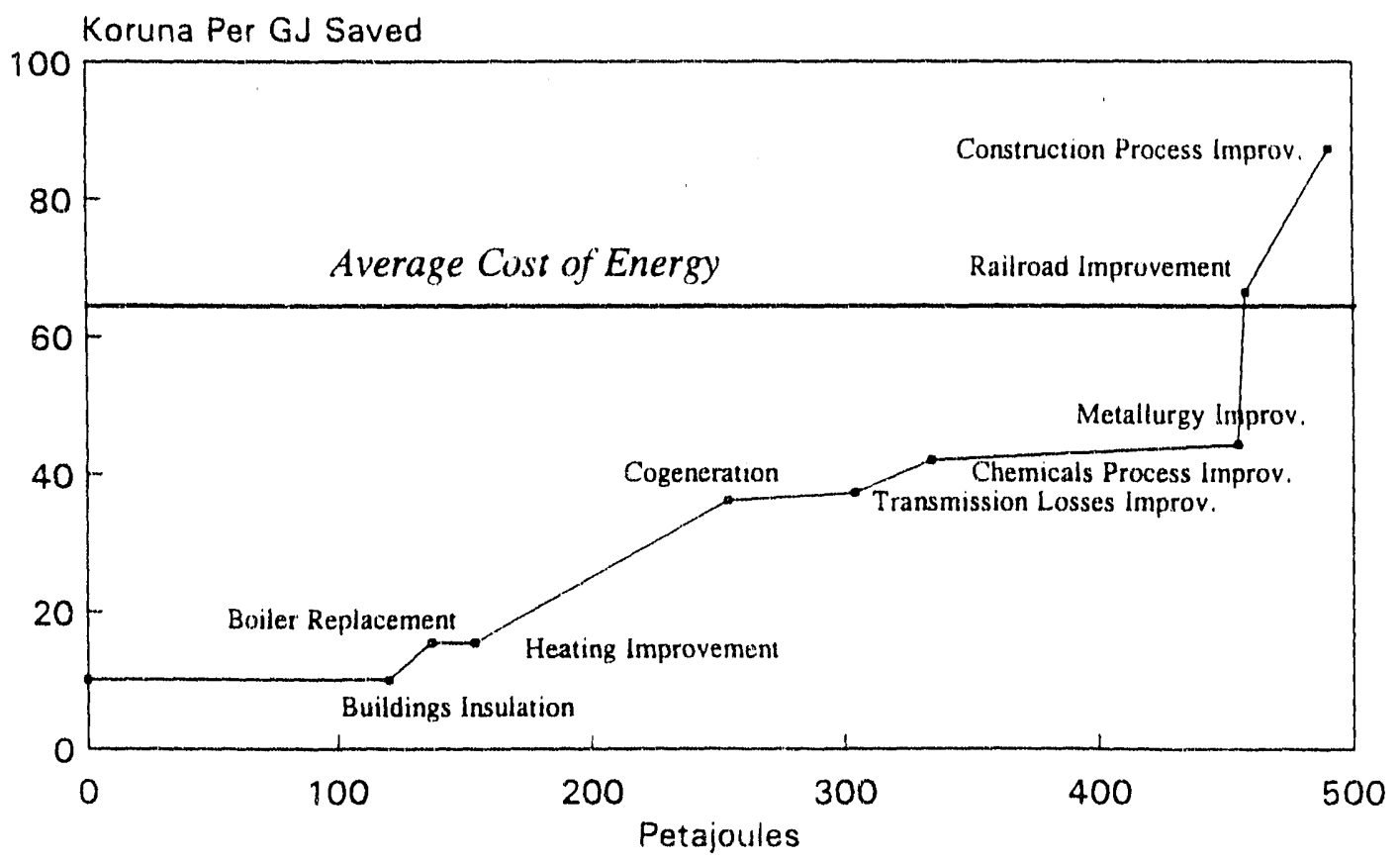

Figure 7. Energy Efficiency Potential in Czechoslovakia Net Costs of Energy Saved to the Year 2010 (Source: Authors) 
payback period of about tive years. Note, however, that this includes insulating existing buildings.

General industry: replacement of boilers that are more than 25 years old with new ones which are only 5 percent more efficient can save an additional 17 PJ. The technology is readily available on the domestic market and does not need to be imported for precious hard currency. The payback period would be less than three years.

Transportation sector: mass production of 4105 liter $/ 100 \mathrm{~km}$ cars. It is quite possible that this could be accomplished in Czechosilovakia by the end of the century with appropriate energy-efficiency policy. This ratio compares to the 7 to 8 liters $/ 100$ $\mathrm{km}$ cars currently being produced in the country.? With other concerted efforts in truck and bus production, and proper incentives to increase rail transport by at least 50 percent, along with alternative transportation policies, Czechoslovakia can save 150 PJ by the year 2030 compared to the Base Case Scenario. ${ }^{10}$

The cumulative cost-effective energy-savings potential identified in Czechoslovakia comes to more than 570 PJ per year. Note that these savings do not include changes in energy consumption due to structural changes in the economy. The levelized cost of this potential is 15.4 billion koruna per year ( $\$ 550$ million), assuming a 7 percent discount rate. The annual cost of supplying the same amount of energy, even when taking account of the current subsidized average cost of energy of 60 koruna per gigajoule, would be more than 34 billion koruna ( $\$ 1.2$ billion) (Figure 7).

On the whole, cost-effective energy efficicncy can save about 0.8 exajoules (EJ) by 2030 compared to the Structural Change Scenario, and 1.4 EJ compared to the Base Case Scenario. This represents a reduction of $0.7 \mathrm{EJ}$, or 22 percent of current energy demand. Carbon emissions under this scenario drop to 72 percent of the current level by 2005.

\section{Interfuel Substitution Scenario}

Under the Interfuel Substitution Scenario, the structure of the primary energy balance would change in conjunction with measures altering the industrial output in Czechoslovakia and improving the technical efficiency of energy use in all economic activities. We also evaluated the potential for Czechoslovakia to reduce consumption of brown and hard coals by increasing its consumption of natural gas. It is generally aceepted that coal is less efficient than natural gas."

A reduction in the consumption of brown coal would primarily affect its use in electricity and heat generation. Higher utilization of natural gas, mainly for decentralized heat production and partially for power production in cogenerating plants, could have significant ecological benefits. Energy savings of 100 to $125 \mathrm{PJ}$ can be achieved by replacing coalfired facilities at the end of their lives with new gasburning technology. To cover these natural gas needs, Czechostovakia would have to import about 20 billion $\mathrm{m}^{3}$ ( 700 cubic feet) in 2000 and 25 billion $\mathrm{m}^{3}$ (880 cubic feet) in 2010, or twice the current imports from the former Soviet Union. This would reduce carbon dioxide emissions by about 1 million tous per year.

We considered the effect of additional government policies on the fuel supply in Czechoslovakia. Even under a high growth scenario for electricity consumption, phasing out electricity exports, reducing electricity losses--saving $6.1 \mathrm{TWh}$, and utilizing nuclear power from plants currently under construction would avert the need for additional fossil fuelgenerating power plants. This means that even if electricity consumption grows by 1.6 percent per year-an unlikely scenario--there will be no need for new electricity generation from fossil fuels.

If, on the othe ' ' nd, electricity consumption grows at the more likely rate of 0.2 percent per year, a scenario which ass. nes an energy-efficiency policy, nuclear power could displace about 17 TWh of coalgenerated electricity, reducing carbon dioxide emissions by about 4 million tons of carbon (Figure 8). However, it is uncertain whether the people of Czechoslovakia will accept the nuclear power option.

The combined strategies of economic restructuring, energy efficiency, and selective interfuel substitution can reduce carbon dioxide emissions by well over 20 percent of their current level by the year 2005. The costs associated with such a reduction would be zero or negative. About half of the reduction would be associated with economic restructuring in the 
Table 14. Selected National Energy Savings and Their Costs in Czechoslovakia

\begin{tabular}{|c|c|c|c|c|c|}
\hline Measure & $\begin{array}{c}\text { Total } \\
\text { Cost } \\
\text { (Billion Koruna) }\end{array}$ & $\begin{array}{l}\text { Energy } \\
\text { Savings } \\
\text { (PJ/Year) }\end{array}$ & $\begin{array}{l}\text { Lifetime } \\
\text { (Years) }\end{array}$ & $\begin{array}{l}\text { Levelized } \\
\text { Cost } \\
\text { (Million Koruna) }\end{array}$ & $\begin{array}{c}\text { Cost of } \\
\text { Conserved Energy } \\
\text { (Koruna/(j,J) }\end{array}$ \\
\hline Existing Builuings Insulation & 11 & 120 & 25 & 10.94 & 7.8 \\
\hline Boiler Replacement & 2.4 & 17 & 15 & 0.26 & 15.5 \\
\hline Improved Efficiency in Heating & 2,4 & 17 & 1.5 & 0.26 & 15.5 \\
\hline Cogeneration & 33 & 100 & 20 & 3.12 & 31.2 \\
\hline Improved Transmission Losses & 17 & 50 & 15 & 1.87 & 37.3 \\
\hline Improved Chemicals Production & 11.5 & 30 & 20 & 1.09 & 38.2 \\
\hline Improvements in Ferrous Met. & 48,9 & 121 & 25 & 4.2 & 34.7 \\
\hline Railroad Improvements & 1.8 & 3 & 25 & 0.16 & 51.9 \\
\hline Improvements in Construction & 26.5 & 33.3 & 25 & 2.27 & 68.3 \\
\hline TOTAL & 1.54 .51 & 491.3 & . & $14.16^{\circ}$ & - \\
\hline
\end{tabular}

- For the first 15 years.

Sources: Simunek, et al., 1987; Synek. ct al., 1988; Vlach, 1989; and others. ${ }^{12}$

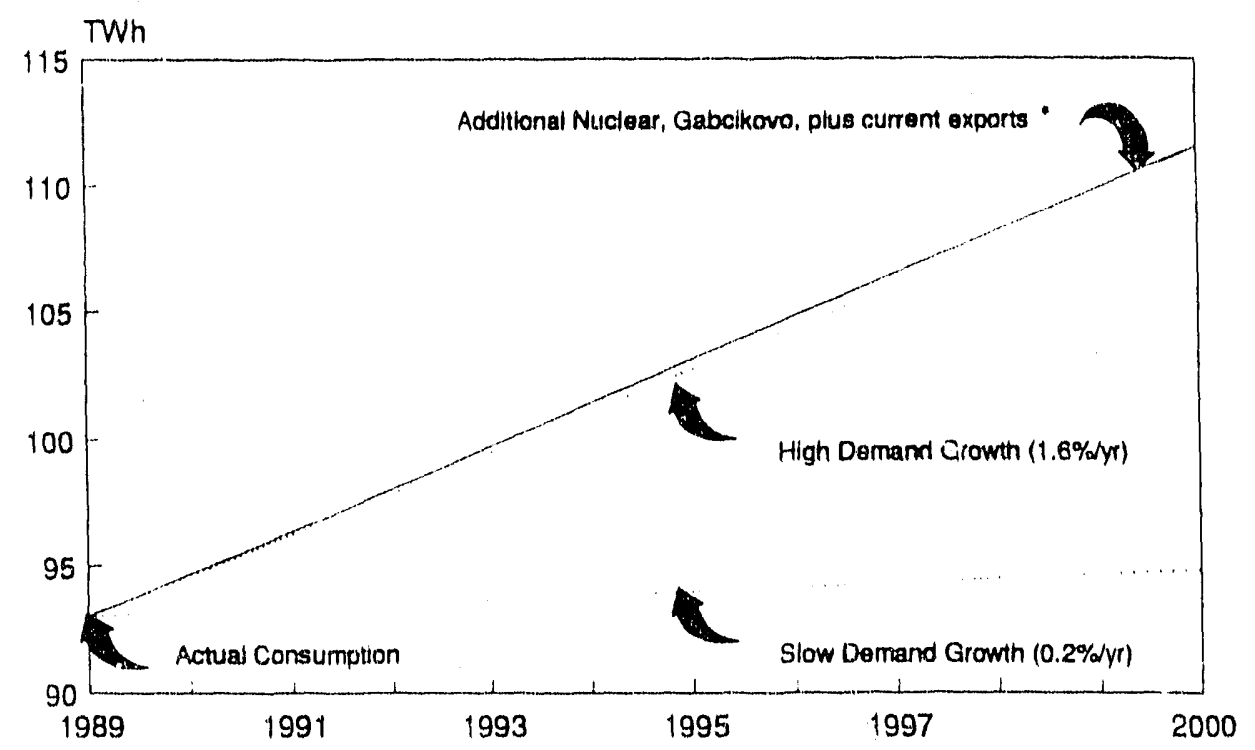

- Gabcikovo is a hyrdo-electric dam in Slovakia currently under construction.

Figure 8. Electricity Demand and Production in Czechoslovakia (Source: Authors) 
country. The industrial sector is expected to sharply reduce the production of steel, aluminum, chemicals, and other energy-intensive products. These changes will bear costs, including lemporary unemployment, reduced export earnings, and economic recession. However, these changes should occur if the country is to achieve an optimal macroeconomic balance. In the long run, these costs will be outweighed by the benedits.

The energy-efficiency measures identified go bevond structural changes in the economy, but they also offer negative costs. They save energy at a lower cost than it takes to supply new energy in Czechoslovakia. Overall, those measures would save the Czechoslovak economy $\$ 650$ million over the next 20 years.

\section{POLICIES FOR CARBON DIOXIDE EMISSIONS REDUCTION AND INTERNATIONAL IMPLICATIONS}

Global energy-related anthropogenic carbon dioxide emissions total approximately 6 billion tons of carbon annually. The industrially developed countries contribute most of the carbon emissions, whereas the developing countries contribute the least. Czechoslovakia releases 4.1 tons of carbon dioxide in the form of carbon per capita per year, about a ton less than the United States. Most developing countries in the world today, however, release no more than one-half to three-quarters of a ton of carbon per capita (Figure 9).

Czechoslovikin can assume a much more active role than in the past in protecting its own resources, as well as the global environment. One of the most effective ways to reduce emissions of carbon dioxide and other pollutants is by increasing the efficiency of energy use. Abating coal and heavy fuel oil combustion at the point of cousumption, curbing heat demand from central heating systems, and replacing coal with natural gas can lead to reduced carbon emissions.

The practical option for reducing carbon emissions is to decrease energy consumption. We explored ways for directing Czechoslovakia's energy policy towards curbing primary energy corisumption in order to achieve a decrease of at least 25 to 30 percent by 2005 to 2010 coripared to the present level. Combining such a radical decrease in energy consumption with the need for economic growth presupposes major changes in all levels and sectors of the Crechosloyak economy. Economic incentives, legislative measures, and international cooperation will all be crucial in achieving this goal.

\section{ECONOMIC INCENTIVES AND DISINCENTIVES}

Reducing carbon emissions in C\%cchoslovakia will require a concerted effort on the part of the government to combine economic reform, industrial restructuring, and a determined policy to implement energy efficiency in all sectors of the economy. A functioning market economy is the first and most important prerequisite. The economic problems which have accumulated in Czechoslovakia during past 40 years present a serious task tor the present Czechoslovak leadership. The basic reform steps must include the following elements:

- Assurance of a non-inflationary situation on the macro-level by means of restrictive monetary and fiscal policies

- A new definition of ownership for all economic actors and the creation of new economic subjects such as private enterprises and stock corporations, accompanied by the transformation of existing state enterprises into enterprises of a different type

- The resolution of price subsidies and the gradual transition to price liberalization.

More significantly, the governınent would have to pursue a policy designed to lower the energy intensity of the economy. Energy intensity per unit of output should decline in order to achieve an absolute reduction in energy demand in Czcchoslovakia.

Government regulation in the market should incorporate the following goals in the near future:

- Setting marginal prices for fuels and energy based on principles of price lists and tariffs 
- Policy measures 10 reflect the actual state of natural luel reserves, requiring payment of a mining rent, and evaluation of fuel reserves

- Incentives and programs for de-emphasiz. ing energy-intensive industries;

- National scientific and technological investment, ccological programs, R\&D for longuterm applications of nuclear energy, nuclear safety, and linking the Czechoslovak power network with the European Community's system

- Preparation and introduction of coal mining reduction programs

- Development ol a regulatory environment for the utility industry which would encourage energy efficiency.

\section{LEGISLATION AND REGULATORY PROVISIONS}

Czechoslovakia can facilitate structural changes and energy efficiency through its existing legal mechanism. Legislation and regulatory policy can remove biases against energy efficiency and aiternative sources of energy. By eliminating distortions, such as subsidies for fossil fuel production and tax policies that favor operating costs over long-term investments, legislation can make energy efficiency more competitive with energy supply. Similarly, including external costs associated with energy production in the price of energy will make energy efficiency and alternative energy sources much more attractive to energy producers and consumers.

Legislation and regulation can go even further and actually introduce laws that favor energy efficiency over energy production. Energy-efficiency standards for domestic and imported appliances, automobiles, lighting equipment, thermal emissivity of buildings, and passive solar features in multi-family housing complexes could be the first step in this direction. It is equally important that all new dwellings are required to have individual temperature control and consumption metering systems.

Concentrated efforts are needed to update and revise current tax and business acts, and to educate energy consumers.
A series of tax statutes could be introduced to favor energy efficiency at the enterprise level, including:

- Provision of low interest bank credits for instilutions and individuals to purchase and install cnergy-saving equipment and devices

- Corporate income tax exemptions over several years for companies with foreign participation (1) manufacture energy-efficient and pollutioncontrol equipment and machinery

- Lifting import duties on all lechnoling and equipment that have applications for energy savings.

\section{INTERNATIONAL COOPERATION}

During this transitional period, the way in which Czechoslovakia opens itself to the world will be a crucial determinate of its future. The country is now in a similar position to that of western Europe at the end of World War II. Czechoslovakia will need help to break away frum its totalitarian past and to heip struggling enterprises which have low labor productivity and obsolete technology to achieve a competitive level. As the United States aided the nations of western Europe alter World War II, so could western democracies help Czechoslovakia today.

Some industries, namely heavy engineering, aircraft and armament production, maintain a well-educated and technically competent work force. These enterprises, with the help of western transfers of capital, management, and technology, could approach western technical standards relatively quickly--in five to seven years. U.S. companies could play an important role in providing know-how, management, and teclinology transfers; these actions would give the United States a stake in central Europe, and would help to diversify the sources of foreign capital in Czechoslovakia.

Fuels with high carbon emissions, such as coal, will be hard to replace with lower carbon-10-energy ratio fuels, like natural gas. The country has depended almost 100 percent on Soviet imports to meet its domestic demand for oil and natural gas. Soviet problems in oil production and export destabilize the oil market in Czechoslovakia and other East and 
Central European countries. Czechoslovakia would benelit from the diversilication of its energy im. ports. Northern African and the North Sea regions hoth have plenty of natural gas and are willing exporters. This strategy, however, is constrained by the lack of transport mechanisms between these regions and C'entral Europe.

In cooperation with its neighbors, Czechoslovakia could construct natural gas pipelines from the North Sea and northern Africa. Italy already operates a natural gas pipeline from Algeria to Italy. Extending this pipeline by about 400 miles would allow it to reach southern Czechoslovakia to provide the needed fuel. I'oland is considering importing North Sea natural gas from Norway via an underwater pipeline. This capacity could be expanded and a pipeline diverted to extend to northern Czechoslovakia.

If automobile and truck transportation in Czechoslovakia grows to match western European trends, the country's oil import bill will increase from the current amount of $\$ 2.5$ billion to approximately $\$ 7.5$

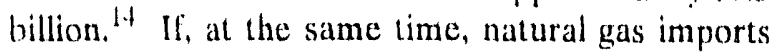
double, the total natural gas import bill would be about $\$ 6$ billion at current prices, and energy imports would cost the country $\$ 13.5$ billion. Clearly, choices must be made to reduce this potential drain on Czechostovakia's budget. It seems that the transportation sector offers opportunity for energy and hard currency savings, rather than limiting natural gas imports. Natural gas is an efficient fuel that can readily replace coal in many applications.

To alleviate the future burden of increased oil impotts, the country can adopt a sensible public transportation policy. The proposed high-speed railroad between Berlin, Prague, and Vienna is just the first step in such a policy. Bus and urban transport systems, already well established, could be expanded and light, high-speed, surface railroads could serve transportation needs in suburban areas.

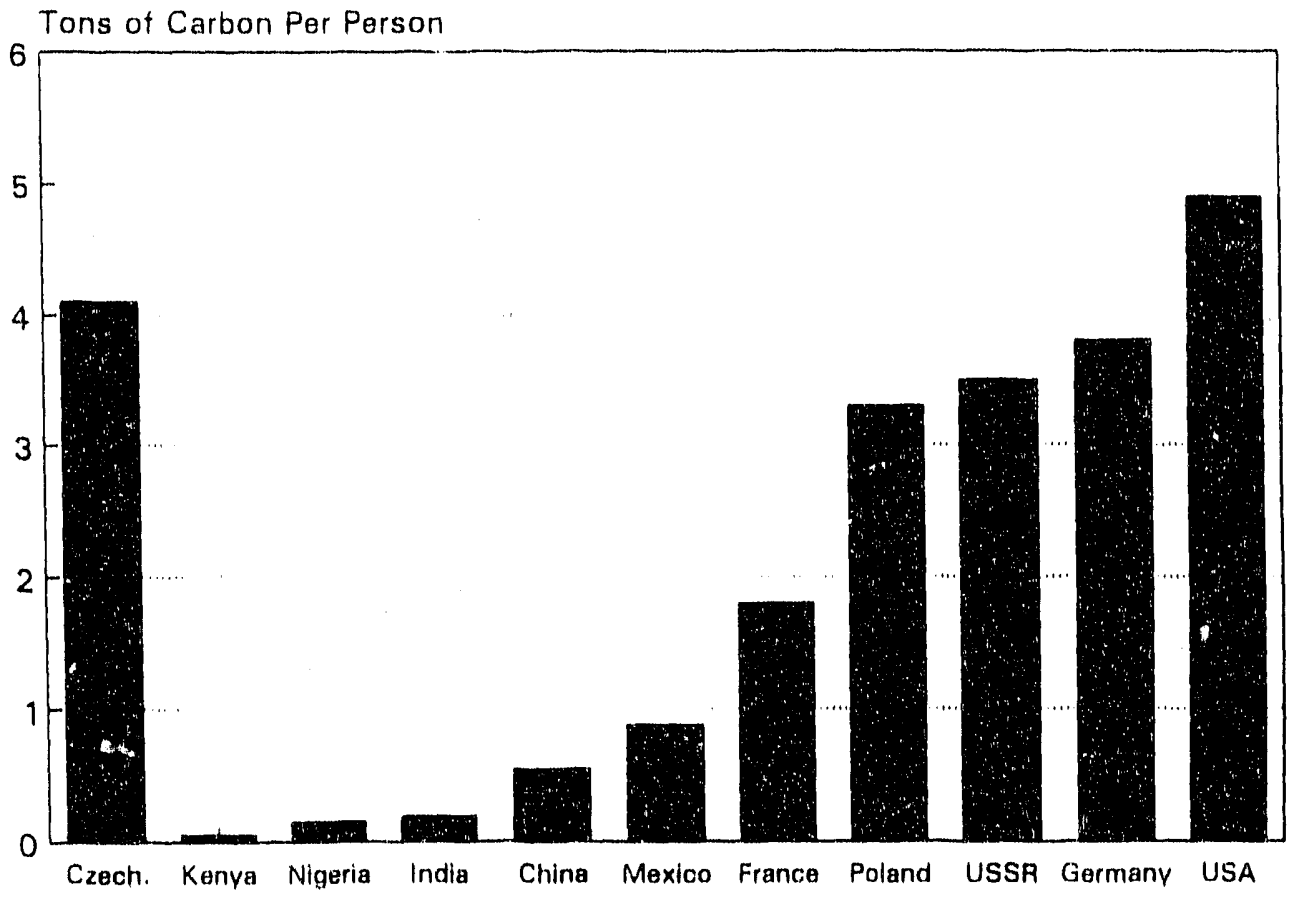

Figure 9. Carbon Dioxide Emissions Per Capita (Source: Oak Ridge National Lab ${ }^{13}$ ) 
The most serious problem the country faces, howcver, is linding markets for goods produced in (zechoslovakia which, up to this point, have only heen offered in exchange for Soviet oil and gas. Soviet-East European energy trade is only now heing conducted in hard currency, and Czechoslovak exports of engineering and consumer products to the former Soviet Union will substantially decrease. Because these products are of lower quality, tinding huyers for them elsewhere will be difficult if not impossible.

The Czechoslovak Minister of Foreign Affairs has recently offered a remedy to improve this situation: the so-called Stabilization Plan for Central Europe and the former Soviet Union. The idea was inspired by the Marshall Plan in post-World War II Europe. Western industrialized countries would create a fund of about $\$ 16$ billion, or 0.1 percent of the GDP of the most developed countries in the world.

Money from this fund would cover exports of goods to the former Soviet Union from enterprises in Poland, Czechoslovakia, and Hungary. The former Soviet Union would repay the value of these imports in rubles by investing in its own economy. The benelits of such an arrangement would be enormous; it would bring more economic stability into Central Europe and the former Soviet republics, and would greatly enhance the chances for political stability in the whole region. Participation by the United States in the fund would be of utmost importance. A similar program, the Cireen Fund, already exists in the World Bank where it serves to help encourage sustainable economic strategies in the developing world.

The nuclear option provides one major benelit--it eliminates carbon dioxide emissions. However, the current risks associated with nuclear power production in Czechoslovakia may be too large. Czechoslovakia should discontinue its reliance on Soviet technology and begin cooperation with the best western producers and suppliers of nuclear technology. An agreement among Czechoslovak and western producers could be made that would allow the production of this technology in Czechoslovakia. A strategy which would rely on imports of readymade nuclear plants to Czechoslovakia would be unacceptable for its economy.

The combined strategies of reducing primary energy consumption through economic restructuring, energy efficiency, and fuel substitution would reduce carbon dioxide emissions in Czechoslovakia from $65 \mathrm{mil}$ lions tons of carbon today to about 40 million tons of carbon in 2005. This would be a significant step in the right direction. Czechoslovakia would improve its economy, clean its air, and contribute to the solution of one of the most important environmental puzzles of the day--global warming. 


\section{ENDNOTES}

1. Marer, Paul. 1985. Dollar GNP's of the USSR and Eastern Europe. A World Bank Publication,

John's Hopkins University Press, Baltimore and London.

Central Intelligence Agency (CIA). 1989. Handbook of Economic Statistics. CPAS 89-10002,

Washington, D.C.

Calculated from Marer's 1980 (BNP (adjusted purchasing power parity) using the Central Intelligence Agency's 1980 to 1989 estimated GNP growth rate (assuming zero (iNP growth rate for 1990), and an implicit price deflator.

2. Institute for Forecasting. Czechoslovak Academy of Sciences, Prague, Czechoslovakia.

3. Henel, M. and B. Cabicar. September 1990. Vyzkumny ustav palivoenergetickeho komplexu, Rentabilita statnich prostredku, vlozenych na podporu vyssihc zhodnocovani paliv a energie $v$ narodnim hospodarstvi - ekonomicke zduvodneni a oblasti pusobnosti, Prague, Czechoslovakia.

4. Nove, Alec, (ed.). 1982. "The East European Economies in the 1970s." Central Intelligence Agency, Handbook of Economic Statistics, (1989).

5. The EPA end-use model projects future energy demand to the year 2030 in five-year increments, giving results for the major fuel types as well as future aggregate industrial energy intensity. It estimates energy demand on the basis of economic growth, structural change, price response, and technical energy-efficiency improvements not attributable to price response.

6. The five SIC sectors specified in the EPA model are: ferrous metallurgy, non-ferrous metallurgy, chemicals, paper \& pulp, and the stone, cement, and glass industries.

7. In the EPA model, personal consumption is identified as residential square footage per capita, appliance share in residential energy consumption, and automobile, bus, air, and rail transportation.

8. This amount includes distribution costs. Nuclear electricity costs without distribution are still 335 koruna per $\mathrm{MWh}$, more than wice the cost of identified electricity savings.

Source: Henel and Cabicar. 1990.

9. The Czechoslovak car, Skoda, achieves favorable fuel economy only by having its engine 25 percent smaller than western cars with a comparable fuel economy. Fuel efficiency, as opposed to fuel economy, is therefore much lower in the Skoda than in most western cars.

10. We assume that the transportation sector, without an energy-efficiency policy, would increase its share in final energy demand from 4 percent today to about 15 percent by 2030 . In the Base Case Scenario, this would mean tripling transportation energy consumption. With the production of more fuel efficicut cars and an increase of rail transport by 50 percent, transportation energy demand would still double.

11. The best achievable efficiency in a conventional, coal-fired power plant is around 34 percent. A natural gas-tired power plant, which requires one third of the capital of a coal plant, achieves efficiency close to 50 percent. The difference is that coal is burned to produce heat, which makes steam, which then drives steam turbines to produce electricity. Gas, however, can be used to power a gas turbine directly, without having to heat large amounts of water to produce steam. 
See: Electric Power Research Institute. 1986. TACi: Technical Assessment (inide, Vulume 1:

Electricity Supply. EPRI P-4463-SR: and Scientific American. September 1990). Special lssue, p.133.

12. Michalicka, Jiri. June 1989. "Zakladni verze projektu v oblasti paliv a energie." SPEV, Prague, Cachoslovakia.

Simunek, Vaclav, et al. December 1989. "Prognoza energytickeho potencialu konecne spotreby energie do roku 2030 a bilancni zavery \% ni vyplivajici." Priloha III, VUPEK. Prague, Ceechoslovakia.

Stastny, personal comments, State Energy Inspectorate, Prague Czechoslovakia.

Synek, Petr, et al. June 1988. "Hlavni technicka reseni pro SCP 02 v oblasti konecne spotrcby ene rgic." VUP'EK, Prague, Czechoslovakia.

Vanis, Jindrich, et al. 1989. "Presneni prognozy konecne spotreby energie do roku 2010." VUPEK, Prague, Czechoslovakia.

Vlach, Josef. October 1989. "Globalni koncepeni studie rozvoje CZT v CSSR." VUPEK, Prague, Czechoslovakia.

13. Oak Ridge National Laboratöry, Oak Ridge, Tennessee.

14. At the price of $\$ 20$ per barrel of oil. This assumption is based on the belief that car ownership per capita will double to approximately 0.4 cars per person, and that miles traveled per vehicle will increase by 50 percent to 8000 miles per year. Also, surplus freight will be transported by motor vehicles, and railroad freight transport be constant. 

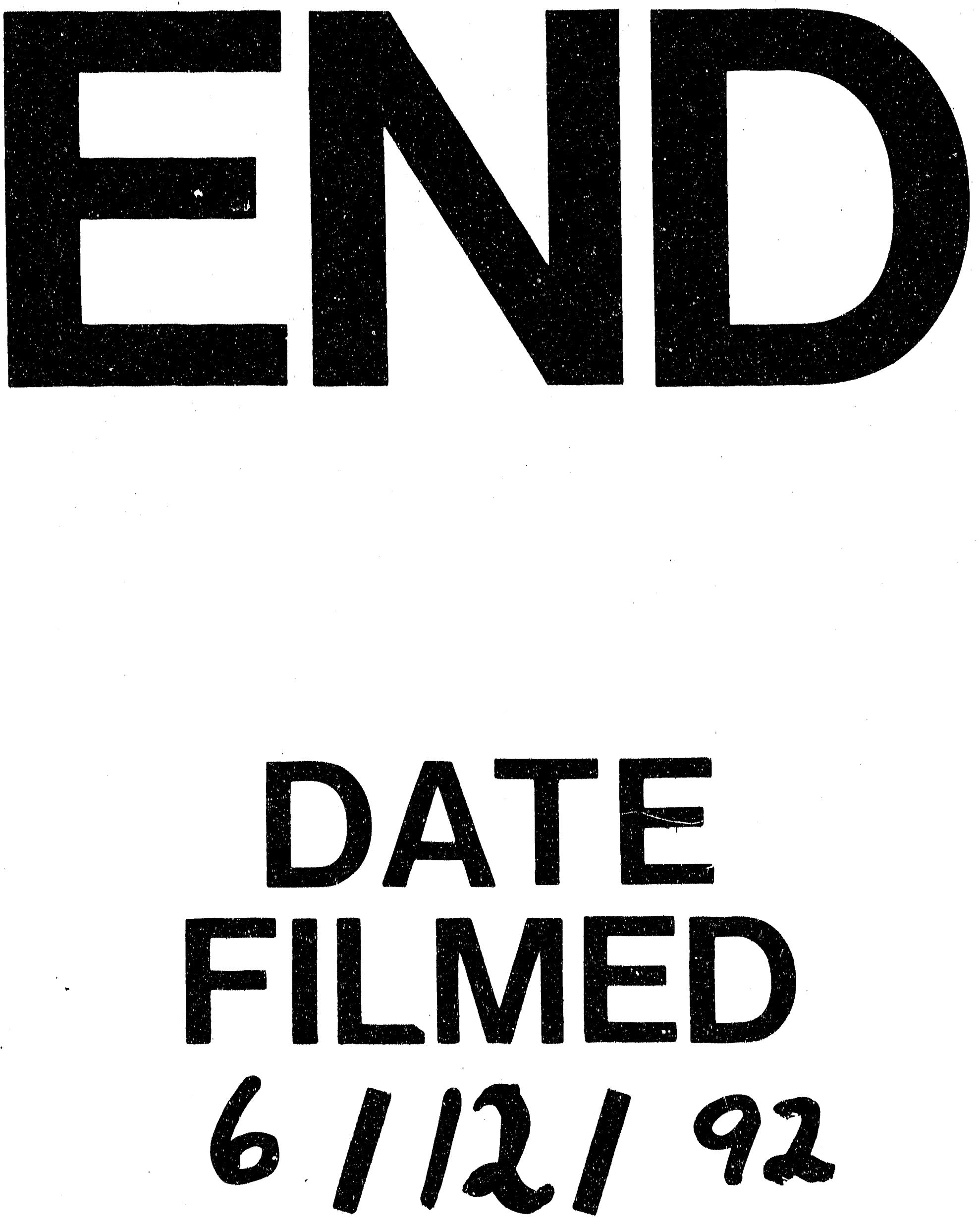

1 
$=$ 